\title{
PENANAMAN ADAB TERHADAP ALQURAN BAGI PARA SISWA DI SD PLUS TAHFIZHUL QURAN (PTQ) ANNIDA SALATIGA
}

\author{
Devia Namira1, Ahmad Fikri Sabiq² \\ ${ }^{1}$ Institut Agama Islam Negeri (IAIN) Salatiga, Salatiga \\ ${ }^{2}$ Institut Agama Islam Negeri (IAIN) Salatiga, Salatiga \\ 1n.devia.dn@gmail.com; ªhmadfikrisabiq@gmail.com
}

https://doi.org/10.36052/andragogi.v9i2.245

Diterima: 11 Oktober 2021 | Disetujui: 22 November 2021 | Dipublikasikan: 31 Desember 2021

\begin{abstract}
Abstrak
Penelitian ini bertujuan untuk mengetahui implementasi penanaman adab Alquran yang dilaksanakan di SD PTQ Annida Salatiga. Penelitian ini merupakan penelitian lapangan dengan pendekatan kualitatif. Teknik pengumpulan data dalam penelitian ini adalah wawancara, observasi, dan dokumentasi. Penelitian ini menggunakan analisis kualitatif, dengan model analisis taksonomi. Adab merupakan pembelajaran yang berkaitan dengan aspek perilaku dan nilai, baik dari segi individu maupun masyarakat. Ada banyak cara dalam menanamkan adab kepada anak, antara lain metode hiwar, metode uswatun hasanah, metode riyadhah, metode Ibrah dan cerita, metode mau'idzah, metode targhib dan tarhib serta metode pepatah qur'ani dan nabawi. Sedangkan beberapa penghafalan Al-Qur'an yang ditanamkan pada anak adalah membangun hubungan baik dengan sang pencipta, menghindari perbuatan yang sia-sia, membangun rasa hormat terhadap Al-Qur'an sebagai kitab suci.
\end{abstract}

Kata Kunci: Pendidikan, Adab, Al Qur'an

\begin{abstract}
This study aims to determine the implementation of the cultivation of the Qur'anic adab which was carried out at PTQ Annida Elementary School Salatiga. This research is field research with a qualitative approach. Data collection techniques in this study were interviews, observation, and documentation. This study uses qualitative analysis, with a taxonomic analysis model. Adab is learning related to aspects of behavior and values, both in terms of individuals and society. There are many ways to instill etiquette in children, including the hiwar method, the uswatun hasanah method, the riyadhah method, the lbrah method, and the story, the mau'idzah method, the targhib and tarhib methods as well as the Qur'anic and prophetic proverb methods. While some of the memorizations of the Qur'an that is instilled in children are to build a good relationship with the creator, avoid useless actions, build respect for the Qur'an as a holy book.
\end{abstract}

Keywords: Education, Adab, Al Qur'an 


\section{PENDAHULUAN}

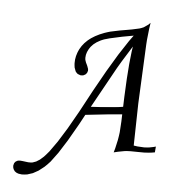

dab merupakan bagian pembelajaran yang sangat berarti yang berkenaan dengan aspekaspek perilaku dan nilai, baik pribadi maupun berhubungan dengan sosial masyarakat. Adab yang baik hendak membagikan pengaruh dalam kehidupan. Sehingga terdapat pepatah yang berkata" adab lebih mulia dari ilmu". Oleh sebab itu nilai yang tercantum dalam agama perlu dikenal, dimengerti, diyakini serta diamalkan oleh manusia Indonesia supaya bisa jadi dasar karakter sehingga bisa jadi manusia yang utuh. Mengingat begitu berartinya adab dalam kehidupan, hingga perihal terkecil juga memiliki ketentuan tertentu (Ali 2011).

Dalam mewujudkan pergantian serta pertumbuhan kearah yang lebih baik, hingga butuh terdapatnya penyesuaian serta realisasi dalam pendidikan dan kehidupan, sehingga tujuan pembelajaran tersebut bisa menciptakan mutu yang baik. Penyesuaian tersebut bisa dicoba dengan kurikulum serta modul pendidikan, proses pendidikan serta pembinaan, dan dengan aktivitas ekstra kurikuler yang terdapat di area tersebut (Arifin 2011).

Fenomena-fenomena yang terjalin dalam dunia pendidikan di kala ini, bagaikan jendela tentang merosotnya adab siswa dalam pelaku pembelajaran, baik dari segi pembelajaran, guru dan siswa. Keadaan tersebut hendak berakibat terhadap mutu pembelajaran yang diharapkan. Salah satu contohnya merupakan adab ataupun etika yang telah terus menjadi jauh ataupun nyaris lenyap dari tiap orang khususnya pada siswa. Perihal itu bisa dilihat dengan banyaknya siswa ataupun mahasiswa yang tidak memiliki sopan santun dalam berdialog, berperilaku dan berpakaian yang tidak cocok dengan konsep ajaran Islam, melanggar akhlak, peraturan sekolah kode etik di tingkat mahasiswa, itu seluruh menampilkan kalau kehancuran moral, akhlak serta adab telah sangat memperihatinkan (Salam 2000).

Sitika menjelaskan bahwa pembentukan akhlak baik pada anak meliputi: (1) Pembentukan akhlak baik pada anak dalam keluarga menurut kajian pendidikan Islam adalah usaha orang tua (pendidik) terhadap anak melalui pembinaan, pembiasaan, pengarahan dan bimbingan serta perbuatan yang baik, mulia lagi terpuji yang dilandasi dengan nilai-nilai Islam yang terkandung dalam Alquran dan Alhadis; dan (2) anak hendaknya menghormati dan menjaga kehormatan orang tua. Anak adalah amanah, apabila amanah ini dapat dijalankan dengan sebaik-baiknya, hasilnya pun akan baik pula, akan tumbuh anak-anak yang saleh dan salehah, anak-anak yang berguna bagi dirinya, keluarganya dan masyarakatnya, baik di dunia maupun di akhirat (Sitika 2018).

Ada banyak metode dalam menanamkan adab kepada anak. Pertama, metode hiwar yang berarti mengadakan percakapan atau dialog sehingga dapat meyakinkan anak. Metode ini dapat dikembangkan menjadi metode diskusi, tanya jawab. Selain bagus untuk menanamkan adab, cara ini juga bagus untuk membangun kedekatan antara anak dan orang tua. Kedua, metode uswatun hasanah (suri tauladan) contohnya keteladanan dari kehidupan Nabi Muhammad Saw. yang mengandung nilai pedagogis bagi para pengikutnya. Ketiga, metode riyadhah (pembiasaan), contohnya membiasakan mencuci tangan sebelum makan, mandi satu hari dua kali, membiasakan mengucapkan salam dan lain sebagainya. Metode ini dikembangkan dengan drill method eksperimen dan demonstrasi.

Keempat, metode Ibrah dan kisah-kisah, metode ini dapat digunakan untuk meyakinkan adab yang baik terhadap lingkungan sosial. Selain itu dapat digunakan untuk meyakinkan adab yang baik terhadap lingkungan sosial. Selain itu dapat digunakan dengan mengambil hikmah-hikmah yang 
terkandung dari kisah-kisah para Nabi, sahabat dan para kekasih Allah, sehingga dapat menimbulkan keteguhan dan kepribadian terhadap Allah, diri sendiri, keluarga maupun terhadap lingkungan sosial. Kelima, metode mau'idzah (peringatan). Keenam, metode targhib (membuat senang) dan tarhib (membuat takut). Ketujuh, metode amtsal (perumpamaan) qur'ani dan nabawi (Sitika 2018).

Sedangkan beberapa adab penghafal Alquran yang ditanamkan kepada anak di antaranya adalah membangun hubungan baik dengan sang pencipta, yaitu dengan kedisiplinan dalam beribadah, memiliki kepribadian yang mulia, dengan menjauhi perbuatan yang sia-sia serta selalu menghiasi diri dengan akhlak yang mulia, membangun rasa hormat terhadap Alquran sebagai kitab suci, dengan menjaga adab-adab ketika berinteraksi dengannya, seperti harus selalu dalam keadaan suci ketika menyentuhnya dan meletakkannya pada tempat yang lebih tinggi serta bersih (Muazzir, Alim, and Al-Hamat 2019).

\section{METODE PENELITIAN}

Penelitian ini merupakan penelitian lapangan (field research) dengan pendekatan kualitatif. Kehadiran peneliti dalam penelitian ini adalah sebagai pengamat yang tidak berpartisipasi atau berperan serta dengan obyek penelitian. Lokasi penelitian ini adalah di SD Plus Tahfizhul Quran (PTQ) Annida Salatiga. Alasan pemilihan lokasi ini adalah dikarenakan sekolah tersebut merupakan lembaga formal tingkat sekolah dasar yang memiliki program tambahan khusus berupa hafalan Alquran. $\mathrm{Di}$ tempat ini, peneliti melakukan penelitian bagaimana pelaksanaan penanaman adab terhadap Alquran kepada siswa.

Teknik pengumpulan data dalam penelitian ini adalah wawancara, observasi, dan dokumentasi. Narasumber dalam wawancara dalam penelitian ini meliputi guru yang mengajar program tahfizhul qur'an di lembaga tersebut. Observasi dilakukan terhadap kondisi sekolah dan berbagai kegiatan berkenaan pembelajaran menghafal Alquran di dalamnya seperti ruang kelas, sarana prasarana belajar, proses pelaksanaan program, dan sebagainya. Observasi model seperti ini disebut sebagai observasi nonpartisipan, yaitu peneliti tidak terlibat aktif dalam kehidupan informan, tetapi hanya menjadi pengamat independen. Sedangkan dokumentasi dilakukan terhadap dokumendokumen yang berkaitan dengan program menghafal Alquran ini seperti dokumen profil sekolah, data lulusan, profil guru, dan sebagainya.

Penelitian ini menggunakan analisis kualitatif, dengan model analisa taksonomi yang didasarkan fokus pada domain, dan hanya satu karakteristik yang sama (Sugiyono 2015). Model ini menganalisis hasil wawancara dari narasumber dengan hasil observasi dan dokumentasi yang ada di lapangan.

\section{TEMUAN DAN PEMBAHASAN}

Berkenaan dengan hasil wawancara kepada para narasumber, diperoleh hasil sebagai berikut: Pertama, pandangan para guru mengenai adab.

"Disebutkan bahwa adab merupakan sopan santun, unggah ungguh, ta'dhim (Annas). Adab adalah norma / aturan dalam bersikap mengenai sopan santun kepada siapapun dan apapun yang di dasarkan atas aturan agama terutama agama islam (Khoir). Cara berperilaku positif sesuai aturan agama islam (Maftukhah). Adab itu segala kegiatan, gerak gerik seorang insan. Tanpa adab, seseorang akan jauh dari kemanfaatan dan keberkahan. Dalam Islam, adab lebih diutamakan sebelum ilmu. Ilmu tanpa adab, akan salah jalan dan tempat. Maka dari itu, yang membedakan manusia dengan makhluk lainnya, salah satunya dengan adanya adab. Karena adab itu 
cerminan dari segala isi yang ada di hati maupun pikiran. Seseorang dipandang baik, ketika memiliki adab yang baik pula. Pada intinya, perbaikilah adabmu sebelum apapun (Akhid). الأدب فوق العلم, arjadi adab itu di atas ilmu (Arif)."

Hasil dari wawancara di atas sesuai dengan apa yang disebutkan bagi al- Attas, secara etimologi (bahasa); adab berasal dari bahasa Arab ialah addaba- yu' addibu- ta' dib yang sudah diterjemahkan oleh al-Attas bagaikan' mendidik' ataupun' pembelajaran' (Al-Attas 1996). Dalam kamus Al-Munjid serta Angkatan laut ( $\mathrm{AL})$ Kautsar, adab berhubungan dengan akhlak yang memilki makna budi pekerti, perangai, tingkah laku ataupun tabiat cocok dengan nilai- nilai agama Islam (Ma'ruf and Al-Habsyi n.d.). Sebaliknya, dalam bahasa Yunani adab disamakan dengan kata ethicos ataupun ethos, yang maksudnya kerutinan, perasaan batin, kecenderungan hati buat melaksanakan perbuatan. Ethicos setelah itu berganti jadi etika (Ma'ruf and Al-Habsyi n.d.).

Bagi al-Attas, sumber kata adab tersebut berlandaskan dalam suatu hadis Rasulullah Saw. yang secara jelas mengunakan sebutan adab untuk menerangkan tentang didikan Allah Swt. yang ialah sebaik-baik didikan yang sudah diterima oleh Rasulullah Saw. Hadis tersebut merupakan: "Addabani rabbi fa'ahsana ta'dibi": Saya sudah dididik oleh Tuhanku hingga pendidikanku itu merupakan yang terbaik. Ada pula secara sebutan (terminologi), al-Attas mendefinisi adab sebagai sesuatu pengenalan dan pengakuan yang secara berangsur- angsur ditanam kedalam manusia tentang tempat-tempat yang pas dari seluruh sesuatu didalam tatanan penciptaan sedemikian rupa, sehingga perihal ini membimbing ke arah pengenalan dan pengakuan tempat Tuhan yang pas di dalam tatanan bentuk serta kepribadian (Al-Attas 1996).

Kedua, mengenai seberapa penting penanaman adab sejak dini.
"Disebutkan bahwa penanaman adab sejak dini ini penting sekali, karena kebiasaan terhadap anak akan selalu dibawa ketika dewasa (Annas). Karena pendidikan dasar adalah waktu yang paling baik untuk belajar etika atau adab agar ketika besar selalu besikap sesuai adab dan tidak sembarangan (Khoir). Sangat penting, karena untuk menanamkan karakter yang baik dan sesuai dengan agama Islam dimulai sejak dini (Maftukhah). Sangatlah penting penanaman adab sejak dini. Pendidikan anak di masa kecil itu yang akan menentukan masa dewasanya. Ketika sejak kecil sudah ditanamkan adab yang baik dan dipertahankan, maka akan ia bawa sampai dewasa, begitu juga sebaliknya. Dalam Islam juga menekankan adab terlebih dahulu. Ketika ada anak kecil tidak ditanamkan adab, sudahlah bisa diprediksi kemungkinan besarnya, walaupun tak pasti. Lain lagi, adab itu tidak bisa diajarkan dalam waktu sekejab. Maka perlu ada pembiasaan dan berkelanjutan. Sehingga semakin cepat diajarkan adab, maka semakin cepat ia bisa menanamkan dalam dirinya. Untuk itu, ajarkanlah anakmu adab sedini mungkin (Akhid). Penting Sekali, dikarenakan dengan adanya penanaman adab sejak dini mungkin, nantinya anak akan terbiasa melakukan sesuatu sesuai dengan adabnya. Dan sesuatu yg baik harus dibiasakan, jika sudah dilatih dari sejak kecil, nantinya anak akan terbiasa melakukan sesuatu yang baik-baik. (Aminah). Penting sekali karena anak di zaman sekarang kalau tidak kenal adab, mau jadi apa bngsa kita di masa mendatang? Jadi penting penanaman adab untuk anak sejak dini (Arif). Sangat penting. Karena dengan adab yg baik bisa menjadikan seseorang mulia dan dihargai. (Nur)."

Hasil wawancara di atas sesuai dengan apa yang disebutkan bahwa penanaman adab sejak dini penting. Perihal ini sesuai dengan yang di informasikan oleh $\mathrm{KH}$ Asy'ari membuka karya tulisnya, Adab al-'alim wa almuta'allim, dengan melansir sabda Rasulullah 
Saw.," Hak seseorang anak atas ibu dan bapaknya merupakan memperoleh nama yang baik, pengasuhan yang baik, serta adab yang baik." (Almutaqi and Syah 2013). Berartinya penyelenggaraan pembelajaran keimanan serta ketaqwaan yang sesungguhnya hanya menggambarkan penerapan perintah UU Nomor. 20 Tahun 2003 pasal 3 tentang Sistem Pembelajaran Nasional mengamanatkan bahwa pembelajaran nasional berperan meningkatkan keahlian dan membentuk sifat serta peradaban bangsa yang bermartabat dalam rangka mencerdaskan kehidupan bangsa, bertujuan untuk berkembangnya kemampuan partisipan didik agar jadi manusia yang beriman serta bertakwa kepada Tuhan Yang Maha Esa, berakhlak mulia, sehat, berilmu, cakap, kreatif, mandiri dan jadi masyarakat negeri yang demokratis serta bertanggung jawab.

Muhammad Nur Abdul Hafizh Suwaid mengatakan bahwa, pentingnya adab dan penanaman adab dalam diri anak-anak terlihat sangat jelas ketika kita melihat Rasulullah Saw. memberikan perhatian terbesar pada adab dalam membentuk akhlak anak. Sampaisampai beliau menanamkannya dalam diri anak dan membiasakannya dengan adab tersebut agar menjadi salah satu tabiat dan sifat dasarnya. Dan disebutkan bahwa penanaman sikap ini lebih baik dibandingkan bersedekah, kendati sedekah begitu penting dalam Islam (Suwaid and Hafizh 2010).

Ketiga, mengenai cara penanaman adab kepada siswa.

"Disebutkan bahwa dengan mencontohkan perilaku sopan santun guru terhadap siswa (Annas). Dimulai dari kita sendiri mencontohkan dan mempraktekkan (Khoir). Dengan memberikan penjelasan secara langsung. Dengan memberikan teguranteguran yang sopan kepada anak setiap kali melakukan kesalahan (Maftukhah). Cara penanaman adab bisa melalui banyak hal disesuaikan dengan kondisi anak. Semakin banyak langkah kita dalam menanamkan adab, maka akan semakin tertanam ke dalam diri anak. Yang perlu kita perhatikan yaitu metode yang kita lakukan, keteladanan, pembiasaan, dan jika perlu berikan reward dalam setiap tingkah lakunya. Ketika metodenya salah, maka penerimaannya juga salah. Ketika tiada keteladanan dari orang tua dan lingkungan yang baik, juga hanya sebatas ilmu saja tapi tidak teraplikasikan dalam perilakunya. Makanya perlu sebuah pembiasaan, anak itu tidak bisa langsung memiliki adab yang baik. Pertama pasti perlu diingatkan, semakin lama maka akan muncul kesadaran diri. Reward juga sebagai pemacu agar anak melakukan adab itu dengan bahagia. Ketika ia melakukannya dengan bahagia, maka akan semakin mudah diterimanya. Selain itu, perlu adanya pondasi awal berupa akidah dan pengenalan akan diri Rasulullah SAW. Lain lagi, membangun lingkungan yang baik, selektif dalam memilih tayangan dan apa yang sering didengarkan itu juga sangat berpengaruh terhadap anak. Maka, tanamlah adab dengan berbagai langkah, jangan hanya berhenti pada satu langkah saja (Akhid). Pembiyasaan melakukan hal tersebut.karena terkadang anak-anak kurang paham jika hanya dijelaskan,jd alangkah baiknya langsung dipraktekkan dalam keseharian. (Aminah). Perlu ditentukan referensi-referensi buku atau kitab yang sekiranya mendukung terciptnya adab terhadap anak, salah satu contoh kitab ta'limul muta'allim. Setelah menentukan buku baru kita ajarkan sedikit demi sedikit apa itu adab dan lain-lain (Arif). Keteladanan yang baik dan didisiplinkan terus menerus. (Nur)."

Hasil dari wawancara di atas sesuai dengan apa yang disebutkan bahwa cara penanaman adab adalah dengan memberikan keteladanan yang baik, pembiasaan yang terus berulang, reward sebagai hadiah ketika melakukan hal baik dan punishment sebagai hukuman ketika melakukan kesalahan. Hal ini sesuai dengan yang disampaikan oleh Abdurrahman An-Nahlawi sebagaimana 
dikutip oleh Heri Gunawan bahwa cara penanaman adab ada beberapa metode, yaitu: 1) Metode Uswah atau Keteladanan, keteladanan merupakan metode yang lebih efektif dan efisien, karena siswa pada umumnya cenderung meniru gurunya. Metode ini sangat efektif untuk menanamkan nilai-nilai akhlak, disini guru menjadi panutan utama bagi murid-muridnya dalam segala hal. Misalnya kasih sayang, senyum ceria, lemah lembut dalam berbicara, disiplin beribadah, dan tentunya bertingkah laku yang baik. Metode ini sangat efektif untuk diterapkan dalam menanamkan nilai-nilai akhlakul karimah pada diri peserta didik karena tanpa guru yang memberi contoh, tujuan pengajaran akan sulit tercapai. 2) Metode Hiwar atau Percakapan, adalah percakapan silih berganti antara dua pihak atau lebih melalui Tanya jawab mengenai satu topik, dan dengan sengaja diarahkan kepada satu tujuan yang di kehendaki. 3) Metode Qishah atau Cerita, dalam penanaman nilai-nilai akhlakul karimah di sekolah, kisah sebagai metode pendukung pelaksanaan penanaman nilai-nilai akhlakul karimah yang sangat penting, karena dalam kisah-kisah terdapat keteladanan atau edukasi. 4) Metode Amtsal atau Perumpanaan, cara penggunaan metode ini yaitu dengan ceramah atau membaca teks. 5) Metode Pembiasaan, adalah sesuatu yang sengaja dilakukan secara berulang-ulang agar sesuatu itu dapat menjadi kebiasaan. Metode pembiasaan berintikan pengalaman karena yang dibiasakan itu adalah sesuatu yang diamalkan. 6) Metode 'Ibrah atau Mau'idhah. 'Ibrah berarti suatu kondisi psikis yang menyampaikan manusia kepada intisari sesuatu yang disaksikan, dihadapi dengan nalar dan menyebabkan hati mengakuinya. Mau'idhah adalah nasehat yang lembut yang diterima oleh hati dengan cara menjelaskan pahala atau ancaman. 7) Metode Targhib dan Tarhib atau Janji atau Ancaman, Targhib adalah janji terhadap kesenangan, kenikmatan akhirat yang disertai dengan bujukan.
Sedangkan Tarhib adalah ancaman karena dosa yang dilakukan. Metode ini bertujuan agar orang mematuhi peraturan Allah (Gunawan 2012).

Keempat, mengenai apakah dalam menghafal Alquran juga memerlukan adab.

"Disebutkan bahwa ini adalah sebuah keharusan karena cepat lambatnya menghafal jg termasuk bagian bagaimana kita memperlakukan alquran itu sendiri. Barokahnya quran kembali ke pengahafal (Annas). Ya karena itu bagian dari sikap yang wajib bagi para siswa maka perlu di tanamkan sejak dini (Khoir). Sangat perlu. Karena ketika menghafal al qur an juga harus mengamalkan apa yg terkandung dalam Alquran (Maftukhah). Ya sangatlah perlu. Karena Alquran itu bukan halnya buku biasa, namun kitab suci yang perlu diperlakukan dengan baik. Menghafal Alquran itu juga suatu kebaikan. Ketika kita memulainya dengan cara atau adab yang baik maka akan semakin mudah dalam menjalaninya. Selain itu, melalui adab, ilmu itu akan lebih cepat mudah diterima. Lain halnya, menghafal Alquran itu seperti sebuah amanah. Maka harus benar hati-hati dalam menjalaninya, memulainya, dan mengakhirinya. Dengan adab juga akan menjadikan ilmu itu bertahan lama, barokah dan manfaat. Ketika menghafal Alquran dengan adab yang baik, maka Insya Allah ayat Alquran yang dihafalnya teraplikasikan dalam kehidupannya. Terbukti kita lihat banyak kasus para penghafal Alquran yang tidak mencerminkan akhlak yang baik. Kemungkinan besar salah satu faktornya yaitu adab (Akhid). Sangat perlu, apalagi Alquran merupakan kitab suci yg dalam memegang atau pun membacanya saja terdapat adabadab tersendiri. (Aminah). Oh jelas, jadi menghafal Alquran itu bukan sekadar menghafal lafadznya saja, tapi kita di tuntut untuk bisa mengamalkan isi dari alquran tersebut. Contohnya adab sebelum membaca Alquran. Dijelaskan dalam surat alwaqiah $\vee$ ريمسه الا المطهرون jadi tidak boleh memegang 
alquran sebelum berwudhu (Arif). Sangat perlu. Karena dengan beradab akan menambah keberkahan dalam menghafal dan sebagai salah syarat untuk memudahkan dalam menghafal (Nur)."

Hasil dari wawancara di atas diketahui bahwa adab juga diperlukan dalam menghafal Alquran. Hal ini juga sesuai dengan apa yang disampaikan oleh Imam Al-Qathalani, sebagaimana dikutip oleh Mustofa Murad mengatakan bahwa Ahlu Alquran adalah orang-orang yang mengamalkan dan mengaplikasikan (isi kandungan) Alquran, mereka adalah para kekasih Allah yang istimewa di antara manusia, mereka tidak sekadar hafal Alquran tapi mengabaikan batasan-batasan (yang diatur) Alquran (Murad 2003).

Kelima, tentang bagaimana penanaman adab terhadap Alquran untuk siswa SD ketika menghafal Alquran.

"Disebutkan bahwa yang harus dilakukan pertama kali yaitu niat, luruskan niat dengan ikhlas tulus. Kedua, bersuci; minimal berwudhu jika bisa mandi. Ketiga, menutup aurot. Keempat, memakai pakaian yang baik dan lebih baik memakai wewangian. Kelima, awalilah dengan asma Allah, dengan ta'awudz. Keenam, menghadap kiblat. Ketujuh, selalu hadirkan hati dan fokus. Kedelapan, bukan hanya sekedar menghafal, tapi perlu memaknai hikmah yang ada didalamnya. Dan yang terakhir yaitu yakin bahwa yang kita lakukan itu suatu kebaikan, bentuk ibadah, dan hanya karena Allah SWT (Akhid). Yang penting anak-anak harus sering-sering diingatkan dan diberi contoh terkait adab terhadap Alquran (Aminah). Dengan keteladanan dan dibuat peraturan supaya terbentuk kedisiplinan. Baik adab dalam berpakaian, cara menghafal dan memuliakan Alqur'an serta cara memertahankan hafalan dan yang tidak kalah pentingnya adalah adab bagaimana siswa patuh pada perintah guru yang mengajarnya. (Nur)."
Hasil dari wawancara di atas diketahui bahwa penanaman adab terhadap Alquran untuk anak-anak SD adalah harus bertingkah laku terpuji dan mulia, diharapkan sekali selalu tampil serius dan khusyuk. Hal ini juga sesuai dengan apa yang disampaikan oleh Imam Nawawi, yaitu: 1) Harus memiliki perangai dan akhlak yang sempurna. Artinya seorang hafiz Alquran harus mencerminkan akhlak Alquran. Untuk menghiasi diri dengan akhlak Alquran, seorang tahfiz Alquran harus mencontoh akhlak Nabi Muhammad Saw. Nabi merupakan teks Alquran yang hidup, sebagai cerminan dari Alquran, sebagaimana Sayyidah Aisyah berkata: kana khuluquhul qur'an (akhlak Rasulullah tak ubahnya Alquran). $\quad 2$ 2) Harus meninggalkan setiap sesuatu yang dilarang Alquran karena untuk memuliakan Alquran. Artinya seorang hafiz Alquran hendaknya tidak mengabaikan apa yang dilarang oleh Alquran, demi menjaga muru'ah dan kemuliaan Alquran. Imam Fudhail bin 'lyadh menganjurkan kepada seorang siswa untuk menjaga sikapnya, sebab ia diibaratkan sebagai pembawa bendera Islam, ia berkata: "Para siswa adalah pembawa bendera Islam, tidak patut dia bermain bersama orang yang bermain dan lupa bersama orang yang lupa, serta tidak berbicara yang sia-sia orang lain karena untuk mengagungkan Alquran". 3) Harus berjiwa mulia. Artinya seorang hafiz Alquran harus memiliki jiwa yang bersih dari segala prasangka yang buruk kepada orang lain, mejaga lisan dan perbuatannya. Tidak patut bagi siswa kasar (sikapnya), pelupa, lantang suaranya dan pemarah. 4) Harus tawadhu' kepada orang-orang saleh, orang baik dan orang miskin. Artinya seorang hafiz Alquran harus santun kepada semua orang, utamanya kepada orang-orang saleh, dan menyayangi orang miskin. 5) Harus khusyuk jiwanya, tenang dan berwibawa. Artinya seorang hafiz Alquran hendaknya memiliki jiwa yang tenang dalam penampilannya, sabar menjaga dan 
memelihara hafalannya, wibawa dalam ucapannya (Imam Nawawi 43AD).

Sedangkan menurut Ahsin adab terhadap Alquran adalah harus bertingkah laku terpuji dan mulia, yakni berakhlak alquran, melepaskan jiwanya dari segala yang merendahkan dirinya terhadap orang-orang ahli keduniaan, khusyuk, sakinah dan waqar, memperbanyak salat malam, memperbanyak membaca alquran pada malam hari, sebagaimana banyak dilakukan oleh para sahabat Rasulullah (Ahsin 2000).

Keenam, mengenai ada atau tidaknya problematika dalam penanaman adab siswa terhadap Alquran pada siswa, disebutkan bahwa problematikanya ada banyak.

"Kadang dari kita yg lalai dengan adab itu sendiri. Sehingga anak lihat kita tidak seperti yg kita ajarkan (Annas). Siswa yang masih kategori anak-anak terkadang masih sering melakukan kesalahan sehingga harus sering diingatkan dan dibimbing (Maftukhah). Problemanya berupa lingkungan yang saling bertolak belakang atau tidak saling mendukung, belum ada kemauan hati dari anak ataupun orang tuanya, belum ada pembiasaan, dan faktor waktu yang membatasinya (Akhid). Ada, kebanyakan dari anak-anak sering lupa bagaimana harus menghormati Alquran yg sesui dengan adab (Aminah). Ada pastinya, kurang pengetahuan guru terhadap adab terhadap Alquran itu sendiri (Arif). Ada. Anak masih kurang bisa menjaga kondisi suci dan masih teledor dalam memposisikan Alquran pada tempat yang seharusnya. (Nur)."

Hasil dari wawancara di atas diketahui bahwa problematika dalam penanaman adab terhadap Alquran untuk anak-anak SD adalah lingkungan yang tidak mendukung, waktu yang tidak memadai, tidak ada pembiasaan, atau kurangnya pengetahuan guru pendamping. Hal ini juga sesuai dengan apa yang disampaikan oleh Sukron. Kehidupan banyak terdapat ujian dan cobaan, dalam ujian dan cobaan tersebut akan ditemukan dan ditentukan siapa yang menang dan siapa yang kalah. Sama seperti halnya dalam menghafal Alquran pasti terdapat ujian dalam proses tersebut yang terdapat perbedaan antara satu dengan yang lainnya. Jika mereka sudah mampu mengatasi masalahnya, maka mereka akan mendapatkan haknya berupa kesuksesan. Berlaku juga hal sebaliknya, mereka akan mengalami kegagalan jika tidak mampu melewatinya (Sukron and Zaki 2009).

$$
\text { Ketujuh, mengenai bagaimana }
$$

penyelesaiannya problematika yang ada, disebutkan "Ya kembali ke kita dengan cara memberi contoh yang baik (Annas). Sering diingatkan, dibimbing, dan diberikan penjelasan supaya mengerti dan menerima (Maftukhah). Pertama, lakukan penjelasan kepada orang tua agar memberikan lingkungan dan cara perlakuan yang sama terhadap anak. Kedua, sebelum menghafal, lakukan penanaman rohani ke anak. Ketiga, berikan nasihat yang berulang. Dan terakhir, manajemen waktu dan keikhlasan dalam mendampinginya (Akhid). Seperti penjelasan di nomor 5, harus sering-sering dïngatkan dan diberi contoh bagaimana seharusnya bersikap dengan Alquran (Aminah). Jadi perlu di tingkatkan dulu pengetahuan adab terhadap Alquran bagi guru (Arif). Sering diingatkan dan diberi contoh (Nur)."

Hasil dari wawancara di atas diketahui bahwa penyelesaian problematika dalam penanaman adab terhadap Alquran untuk anak-anak SD adalah dengan memberikan contoh dan penjelasan mengenai adab yang baik, manajemen waktu pendampingan dan meningkatkan pengetahuan guru mengenai penanaman abad para penghafal terhadap Alquran. Hal ini sesuai dengan penelitian dari Pratama yang menyebutkan bahwa solusi untuk memperbaiki akhlak santri yaitu dengan memberikan pembiasaan melalui bimbingan keagamaan yang sudah terjadwal di kegiatan panti asuhan 
dalam keseharian, agar santri terbiasa untuk mengikuti alur pola hidup di panti asuhan sehingga mereka secara tidak sadar akan terbiasa dengan kegiatan tersebut. Program ini juga diiringi dengan pembinaan akhlak oleh guru dengan memberikan keteladanan atau contoh perilaku akhlakul karimah sesuai dengan syariat Islam serta dengan melakukan pembinaan melalui pendekatan kepada santri dengan memberikan nasehat, teguran dan peringatan agar mereka tidak melanggar peraturan yang ada (Pratama 2018). Selanjutnya, dalam penelitian dari Sahrudin juga disebutkan bahwa solusi dari problematika penanaman akhlak ini adalah dengan adanya keteladanan yang baik dari para pemimpin dalam mengimplementasikan perencanaan dan pelaksanaan pembinaan akhlak yang baik, serta evaluasi diri dan akuntabilitas dalam program-program yang akan dilaksanakan (Sahrudin 2012).

\section{PENUTUP}

\section{Simpulan}

Adab merupakan sebuah pembelajaran yang berhubungan dengan aspek perilaku dan nilai, baik dari segi individu maupun masyarakat. Pembentukan akhlak baik pada anak dalam keluarga adalah usaha orang tua (pendidik) terhadap anak melalui pembinaan, pembiasaan, pengarahan dan bimbingan serta perbuatan yang baik, mulia lagi terpuji yang dilandasi dengan nilai-nilai Islam yang terkandung dalam Alquran dan Alhadis; dan anak hendaknya menghormati dan menjaga kehormatan orang tua. Ada banyak metode dalam menanamkan adab kepada anak, meliputi metode hiwar, metode uswatun hasanah (suri tauladan), metode riyadhah (pembiasaan), metode Ibrah dan kisah-kisah, metode mau'idzah (peringatan), metode targhib (membuat senang) dan tarhib (membuat takut) serta metode amtsal (perumpamaan) qur'ani dan nabawi. Sedangkan beberapa adab penghafal Alquran yang ditanamkan kepada anak di antaranya adalah membangun hubungan baik dengan sang pencipta, menjauhi perbuatan yang siasia, membangun rasa hormat terhadap Alquran sebagai kitab suci.

\section{Rekomendasi}

Dari penjelasan di atas, peneliti memberikan beberapa rrekomendasi dan saran. Pertama, kepada pihak sekolah bisa mengkaji secara ilmiah mengenai metode penanaman adab agar ke depannya menjadi lebih bagus dan kompatibel untuk di terapkan dalam kehidupan sehari-hari. Selain itu, pada tahap menghafal Al Qur'an siswa juga harus paham akan pentingnya adab dalam menghafal Al Qur'an. Kedua, kepada pihak orang tua agar ikut berpartisipasi dalam penanaman adab yang sudah di terapkan oleh sekolah agar hasil yang diinginkan dapat mencapai tujuan dengan baik. 


\section{DAFTAR PUSTAKA}

Ahsin, w Alhafidz. (2000). Bimbingan Praktis Menghafal Alquran. Jakarta: Bumi Aksara.

Al-Attas. (1996). Konsep Pendidikan Dalam Islam. Terj. Dari Bahasa Inggris Oleh Haidar Bagis. Bandung: Mizan.

Ali, Zainuddin. (2011). Pendidikan Agama Islam. Jakarta: Bumi Aksara.

Almutaqi, and Muhamad Ilzam Syah. (2013). Konsep Pendidikan Akhlak Menurut Hasyim Asy'ari Dalam Kitab Abab Al'Alim Wa Muta'allim. Salatiga: STAIN Salatiga.

Arifin, H. Meter. (2011). Ilmu Pendidikan Islam: Tinjauan Teoretis Dan Praktis Berdasarkan Pendekatan Interdisipliner. Jakarta: Bumi Aksara.

Gunawan, Heri. (2012). Pendidikan Karakter Konsep Dan Implementasi. Bandung: Alfabeta.

Imam Nawawi. (43AD). Al-Tibyan Fi Adab Hamalat Alquran. Beirut: Dar al-Nafais.

Ma'ruf, Luis; Husin, and Al-Habsyi. Kamus Al-Munjid, Al-Maktabah Al-Katulikiyah; Kamus Al Kautsar. Surabaya: Beirut; Assegraff.

Muazzir, Akhmad Alim, and Anung Al-Hamat. (2019). "Penanaman Adab Penghafal Al-Quran Di Sekolah Dasar Islam." Annual Conference on Islamic Education and Social Sains (ACIEDSS) 1(1): 97-104.

Murad, Mustafa. (2003). Kaifa Tahfadz Alquran. Kairo: Dar al-Fajr li al-Turats.

Pratama, M. Farhan Yoga. (2018). "Strategi Bimbingan Agama Islam Dalam Membina Akhlak Anak Asuh Di Panti Asuhan Islahul Muna Kelurahan Tingkir Tengah Kota Salatiga." IAIN Salatiga.

Sahrudin, Endang. (2012). "Pembinaan Akhlak Anak Asuh Di Panti Asuhan Se-Kabupaten Indragiri Hilir: Problematika Dan Solusinya." UIN Sultan Syarif Kasim Riau.

Salam, Burhanuddin. (2000). Etika Sosial (Asas Moral Dalam Kehidupan Manusia). Jakarta: PT Rineka Cipta.

Sitika, Achmad Junaedi. (2018). "Pembentukan Akhlak Al Karimah Pada Anak Usia Dini." Al Hikmah: Indonesian Journal of Early Childhood Islamic Education 2(1): 1-12.

Sugiyono. (2015). Metode Penelitian Pendidikan: Pendekatan Kuantitatif, Kualitatif Dan R\&D. Bandung: Alfabeta.

Sukron, Muhammad, and Zaki. (2009). Menghafal Al-Qur"an Itu Gampang. Yogyakarta: Mutiara Media.

Suwaid, M, and Nur Abdul Hafizh. (2010). Prophetic Parenting. Yogyakarta: Pro-U Media. 